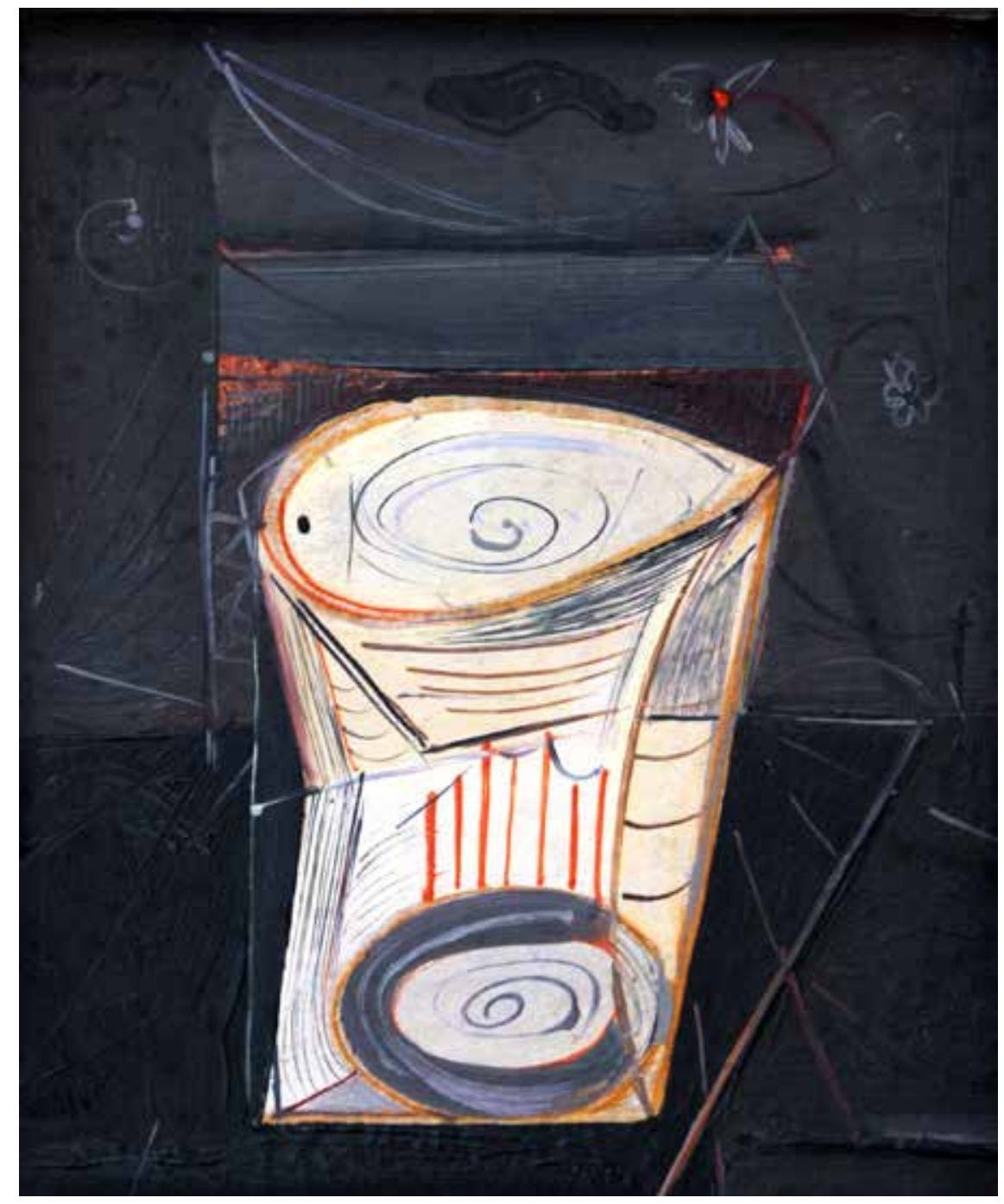

Alejandro Obregón

Líneas

$29 \times 26$

acrílico sobre tabla

1957 



\title{
Alejandro Obregón
}

\author{
Alejandro Obregón
}

\author{
Juan Gustavo Cobo Borda (Colombia)
}

coborda@gmail.com

\section{Resumen}

En este texto, el escritor y poeta Juan Gustavo Cobo Borda presenta un recorrido por la obra de Alejandro Obregón. En el escrito, explora la naturaleza del trabajo del artista y su papel como uno de los más influyentes pintores modernos.

Palabras clave: Obregón, pintura colombiana, pintura, surrealismo, arte abstracto, cubismo.

\section{Abstract}

In this text, the writer and poet Juan Gustavo Cobo Borda presents a survey of the work of Alejandro Obregon. In his writing, he explores the nature of the artist's work and his role as one of the most influential modern painters.

Keywords: Obregón, Colombian painting, painting, surrealism, abstract art, cubism.
Para CItAR este artículo / to CITE thIS ARTICle Cobo borda, J. (2013). Alejandro Obregón. Poliantea IX, (16), pp. 261-297. 
- Alejandro Obregón - Juan Gustavo Cobo Borda 


\title{
Alejandro Obregón
}

\begin{abstract}
Juan Gustavo Cobo Borda (Colombia)
Poeta y ensayista bogotano. Fue director durante una década (1973-1984) de la revista Eco, de la librería Buchholz, y Gaceta, del Instituto Colombiano de Cultura. Ha ocupado cargos diplomáticos en Buenos Aires y Madrid y fue embajador en Grecia. Miembro número de la Academia Colombiana de la Lengua desde 1993, y correspondiente, de la Academia Española. Ha sido jurado tres veces del Premio Juan Rulfo, (Guadalajara, México); del Rómulo Gallegos, (Caracas); del Reina Sofía de poesía iberoamericana (Madrid) y del Neustad, Universidad de Oklahoma, Estados Unidos. Ha colaborado con otras publicaciones, como Plural, de México, ABC, de España, y El Nacional de Venezuela.
\end{abstract}

\section{Introducción}

La obra de Alejandro Obregón (1920-1992) constituye uno de los momentos más altos de la pintura colombiana. Con los instrumentos expresivos de la modernidad plástica (cubismo, expresionismo) abarcó desde la Costa Caribe todo el país y lo recreó en una naturaleza siempre viva, en sus inexorables ciclos de ascenso y caída, de esplendor y ruina, que vivificó con su conciencia de ser ante todo un pintor americano.

Ira y emoción, como ha escrito Edward Shaw, su paleta está en perpetuo movimiento, al romper los límites de la figuración y crear un espacio que fusiona el toro con el cóndor como la mojarra con los alcatraces. Pero ese espacio afín si se quiere a un realismo mágico nunca soslayó el drama del medio siglo de violencia colombiana que padeció y afrontó desde 1948, cuando tomó acelerados apuntes de los cuerpos y la sangre en las calles bogotanas. Ambas vertientes se fusionarían en una obra única, que Juan Gustavo estudió en un libro pionero: Obregón (Bogotá, 1985) y que ahora vuelve, sobre la totalidad de ella, con los renovados aportes al respecto y la conciencia de su cada vez mayor importancia.

Volver a mirar la pintura de Obregón, en su texto, en sus cuadros, en los afiches de algunas de sus exposiciones, es retornar a un mundo único, y muy nuestro, por su entereza y su elocuente valor expresivo. Vale así la pena 
renovar su memoria, en la sensibilidad de las nuevas generaciones.

\section{Origen de un pintor}

La ola, la borrasca, la conflagración de un cielo que se derrumba sobre un mar inquieto, esa apretada superposición de colores, en veladuras y transparencias exquisitas, en racimos de grafías, que conocen en definitiva su fugacidad, ante el desmesurado espectáculo de una tormenta oscura. De unas nubes sombrías, que apagan todo con la fuerza que el hombre no puede doblegar.

Así la lancha se volteará y Bernardo Restrepo Maya, Álvaro Cepeda Samudio, Alejandro Obregón, Juancho Jinete y el propio Gabriel García Márquez contarán, a su modo, la historia: la del náufrago que flotaba como una medusa y Obregón extrajo del agua literalmente de los pelos y tiró al fondo de la lancha como un sábalo. Historias de navegantes. Ciclones del Caribe. Huracanes, cada temporada, con nombre de mujer, como el Katrina, por ejemplo, hoy en día.

A Obregón le gustaban los riesgos. Medir fuerzas. El ponerse a prueba. El gesto físico que revelaba un carácter. Que desde el hombro llegaba a la punta de los dedos para conducir la brocha y trazar asíla delimitación de un espacio. El escenario donde la alharaca del trópico buscaba su final resolución en un silencio muy diciente, pletórico de todo cuando había visto y acumulado.

Un pintor que sabía de memoria mucha poesía inglesa, que había admirado mucha pintura y que rindió homenaje tanto a Zurbarán como a Paul Klee. Que sería muy capaz de irse con León de Greiff al palacio presidencial para decirle a Carlos Lleras que reconsiderara su decreto de expulsión del país de Marta Traba.

Obregón sabía cuándo hacerse presente, en qué momento tomar partido, no propasarse en la obscenidad promiscua de las entrevistas y hablar más bien en tajantes sentencias, un tanto esotéricas, pero debido a su concentración, difíciles de tergiversar: "Dibujar es escribir. Pintar es decir". "Un cuadro no debe representar, debe existir en base a su propia energía". Había llegado a ello, en una larga y laboriosa trayectoria que, por cierto, había sido estudiada bien desde sus comienzos.

En la "Crónica de la moderna pintura colombiana (1934-1957)", de Walter Engel, que en 1957 había publicado la revista Plástica, en dos entregas, se habla de los primeros 
cuadros de Obregón exhibidos en el V Salón Anual de Pintura, de 1944, donde ya se destacaba "Retrato del pintor", por su "refinada sencillez", "iniciación de lo que posteriormente íbamos a llamar 'época gris', o sea el primer estilo claramente definido del pintor que se dio a conocer en Bogotá".

En 1945, en el IV Salón Anual, una pequeña cabeza femenina titulada "Retrato", realizada "íntegramente en brochazos sueltos, enérgicos y audaces: si se quisiera ya desde entonces una buena definición de Obregón era esta. De sus tajantes ángulos cruzándose sin temor.

Pero es el año 1948 titulado por Walter Engel como "Un año cumbre bajo el signo de Alejandro Obregón", el que opone a la tragedia del nueve de abril, incendios, cadáveres, destrucción, saqueos, el esfuerzo creativo. La respuesta del arte.

Exposición individual de Obregón el 28 de abril en la Sociedad Colombiana de Arquitectos. Su época "oscura", donde prevalecen "pardos, azules y grises oscuros, y el negro. $Y$ prevalece también la constructiva y consciente deformación", que mostrará su admirativo reconocimiento del deformador por excelencia: $\mathrm{Pa}-$ blo Picasso.
Ese minotauro de la pintura al cual, hecho curioso, le rendirá un explícito homenaje titulado "Elegía a Picasso", de 1968, con un hombretoro a la izquierda y un cóndor a la derecha, como símbolos muy propios de su tributo, y en el centro los negros ojos penetrantes del español y su sólida cabeza calva, sobre un fondo negro. El monarca nunca destronado del arte moderno que en una ocasión en París colgó un cuadro suyo y le dijo: "Obregón, iqué buen nombre para un pintor!”.

Pero en 1948 otros dos hechos merecen destacarse. Luego de Ignacio Gómez Jaramillo, Luis Alberto Acuña y Miguel Díaz Vargas, Alejandro Obregón es nombrado director de la Escuela de Bellas Artes de Bogotá. Que dependía del Consejo Directivo de la Universidad Nacional, cuyo rector era entonces Luis López de Mesa. Por su parte, la directora del Museo Nacional, Teresa Cuervo Borda, encargará a Obregón la selección de un gran salón de arte contemporáneo que, inaugurado el 12 de octubre de 1948, se conocería como el "Salón de los XXVI" por el número de participantes.

Donde la vieja guardia, por decirlo así, Pedro Nel Gómez, Ignacio Gómez Jaramillo, Luis Alberto 
Acuña, Carlos Correa, Marco Ospina y Alipio Jaramillo, convivirían con las nuevas promesas: Enrique Grau, Eduardo Ramírez Villamizar, Guillermo Wiedemann, Lucy Tejada y Sofía Urrutia, además de Obregón mismo y el escultor Edgar Negret.

El año 1948 concluyó con el "Salón de los Seis", también organizado por Obregón con seis alumnos de la Escuela de Bellas Artes. Escuela que, a pesar de la renovación instaurada (Alberto Zalamea sustituye a Rafael Maya como profesor de Historia del Arte) no parece dar frutos. Ninguno de los seis prosigue ni trasciende.

Sin terminar su periodo como director de la Escuela, Obregón parte con Sonia Osorio en un buque de carga para Francia. Pero ya había dado varios testimonios de su cada vez más sólida vocación pictórica y su presencia pública como animador del arte moderno y las últimas promociones.

Cuando regrese en 1955 se encontrará con otro mundo. Pero resulta interesante destacar cómo desde el año 1944 los pintores ya conocidos escribieron sobre Obregón en forma elogiosa. Hay notas de Gonzalo Ariza, Marco Ospina, Luis Alberto Acuña e Ignacio Gómez
Jaramillo, además del poeta mexicano, residente entonces en Colombia, Gilberto Owen, que así lo reconocen. También lo hicieron los críticos como el ya mencionado Walter Engel, seguidos por Jorge Gaitán Durán, Clemente Airo, Luis Vidales, y el crítico-galerista Casimiro Eiger, más tarde, desde sus programas de la Radio Nacional. No era un panorama tan yermo, como se ha presentado, y la llegada de Marta Traba no hará más que ampliarlo y consolidarlo, con su entusiasmo polémico.

Para referirnos al periodo 19551960 Álvaro Medina en su libro $E l$ arte del Caribe colombiano (2000) hace mención al aporte de los dos maestros costeños, Alejandro Obregón y Enrique Grau, fundamentales en el proceso de renovación:

Bajo la influencia del cubismo órfico, con vagas reminiscencias del cubismo sintético, influencia resuelta en una figuración cruzada de planos geométricos completamente autónomos con relación a los contornos de los motivos que componían las obras, Obregón y Grau marcaban la pauta, el primero con una vasta serie de bodegones simbólicos que giraban casi siempre en torno al duelo y la muerte; el segundo con su fidelidad a la figura humana, que en 1957, declinó fugazmente a favor de la abstracción pura (p. 23) 
Estas eran algunas de las referencias en que se insertaría el trabajo de Obregón en su primera época, que Eugenio Barney Cabrera, en una monografía de 1967 titulada "El itinerario de Alejandro Obregón" subdivide en varias etapas.

Hablaría así Barney Cabrera de una primera etapa "naturalista" anterior a 1944 como "El camión rojo" de 1942. De un periodo francés emparentado con el cubismo (19491954) y de un periodo "gris" que, según algunos, perdura hasta 1961. Doce años de pintura magistral.

Se intercalan allí épocas oscuras (1948) y periodos (1952-1958) formalista con un tema obsesivo: los objetos simbólicos. Aquí bien cabe la observación de Graham Dixon en su soberbio libro sobre Caravaggio (2011):

"Su idea del bodegón no consiste en una reunión de objetos, sino en un teatro de formas" (p. 164).

Los bodegones de Obregón también tienen algo de prestidigitador que monta un escenario donde pueden ir tanto los clavos y el martillo de la crucifixión de Cristo como copas, peces o palomas, cuchillos, flores y frutas. A veces solitarios en su aislamiento; en otras, superpuestos en difíciles equilibrios, pero todos, de algún modo, intentando establecer diálogos y asociaciones, empatías comunicativas. Se consideraba entonces a Obregón como un expresionista romántico, con su contrapunto entre la figuración y una abstracción muy personal y un tanto geométrica que nunca se desprende del todo de la naturaleza. $\mathrm{Al}$ contrario, ella estaba siempre ahí, vuelve a ella. La estudia, fragmenta o descompone. La torna prismática. La abre en una indagación cromática que tiene mucho de cirugía colorística, de pregunta para que forma y color expongan sus secretos. El color emotivo, temperamental, y las formas lapidarias pero no por ello menos naturalistas. Aritmética humana que se hará alfabeto en el solitario retrato de su hijo Diego, de 1955.

Pero Obregón semeja un naturalista con perros y flores, sandías o siluetas de peces, en su "Bodegón en blancos" (1954) o de pájaros como en su "Caballito de bronce" (1956) o de su "Gato" (1958). Cruza la tela con toda clase de líneas y sombras, diversas intensidades de color, la opaca, oculta en alguna forma al animal o el objeto o la ubica de modo impensado y poco convencional. Pero siempre está allí. 
Siempre la naturaleza late con fuerza o con rabia, como lo atestigua su "Desastre ecológico en la Ciénaga de la Virgen", de 1986, donde el trasfondo es de eclipse apocalíptico, de lunas que se extinguen en medio de ese clamoroso repudio de colores que se disgregan en la ruptura de toda armonía. Donde parecen ahogarse en la muerte todos sus peces y todas sus aves.

Podemos retornar, entonces a las caracterizaciones de Barney Cabrera y a sus "particularidades temáticas", para hacernos una idea del surgimiento de Obregón como pintor y del modo como desplegó sus intereses:

\section{Retratos}

2. Los símbolos o temas del litoral o de índole marítima.

3. El tema de la violencia o del drama humano en Colombia.

4. El símbolo del toro y del cóndor.

5. El tema telúrico en general o la voz épica, con utilización del mito.

Símbolo y magia: estas dos constantes del trabajo de Obregón definirían su pintura. En todo caso, la geografía se había tornado emotiva, cargada de fuerza en el lienzo y representaba al país en todos sus extremos climáticos y figurativos, de la barracuda hasta el cóndor. Pero también las formas habían adquirido un dinamismo insospechado, la velocidad de una visión que, de forma simultánea, se desplegaba y se ahondaba. Era el horizonte pero a la vez el primer plano. El nacimiento que brota como un volcán del fondo del mar pero también la clausura donde todo se extingue, y la última flor yace calcinada. Tal el dilatado alcance que logró la pintura de Alejandro Obregón.

\section{Series y constantes}

La primera época de la pintura de Alejandro Obregón, como ya lo hemos adelantado, se caracteriza por el cultivo de géneros tradicionales como los retratos y autorretratos, de sus mujeres como Ilva Rasch o Sonia Osorio, y de ciertas figuras ya emblemáticas de sus posteriores intereses como "El pez dorado", de 1948 y la monumental "Nube gris" del mismo año, con la totémica figura en amarillos, que tiene algo de primitiva deidad indígena precolombina, vista por un moderno Gauguin. La mujer y la nube ocupan sus diferenciados espacios, en una hierática afirmación. 
A retratos y autorretratos, incluido un Bolívar, se añadiría muy pronto uno de sus temas más cultivados: el bodegón.

Sus colores iniciales tendían más hacia los ocres, sienas, pardos y tierras, muy opacos en ocasiones, o ya explorando el gris, en lo relacionado con los dramas sociales y políticos, como la muy picassiana "Masacre del 10 de abril", de 1948, o su "4 de mayo" de 1957, con su explícito letrero de "Muera el tirano", y los tanques de la dictadura de Rojas Pinilla vencidos por inermes tinteros y plumas.

El expresionista figurativo tiende luego hacia una formalización más constructiva, de carácter geométrico, que apela al orden y la síntesis, en reminiscencia del cubismo de Braque. E incluso más atrás, al propio Cézanne, sobre el cual dijo: "El color constructivo a base de pinceladas que iban generando las formas".

Así se armará ahora el lienzo como un vívido mosaico, pleno de variados tonos e intersecciones de planos, donde se aíslan o superponen las figuras símbolos. Frutas, flores, flechas máscaras, copas y jarras, hojas, aletas y garras, cuervos, círculos y medialunas, el cuchillo y la sandía, el número y la letra. El color ya no es sordo ni apagado, sino que se torna vivaz y animado, muy luminoso y en ocasiones deslumbrante. Un viaje, de 1958, por Europa y Estados Unidos lo hará apreciar tanto el informalismo europeo como la Action Painting norteamericana. En todo caso, como lo señaló el crítico Harold Rosenberg al proponer el nombre de "expresionismo abstracto" para la nueva tendencia:

"En un determinado momento, el lienzo empezó a parecerles a los estadounidenses, como una arena en la cual se podía actuar, más que como un espacio en el cual se podía reproducir, re-diseñar, analizar o 'expresar' un objeto real o imaginario". El lienzo se convertiría más en un evento que un cuadro, como lo asumieron figuras como Pollock y Kooning.

La pintura parecía volver hacia una gestualidad despojada de referentes culturales. Que abre el discurso del subconsciente con sus manchas y trazos no controlados, que hacía mira milenarios arquetipos. Al comienzo mismo del mundo, en orígenes que tienen que ver con la matriz del agua o el fuego arrasador del volcán, tal como lo interpreta Obregón hundiéndose en el 
mar y percibiendo lo sísmico de sus pulsaciones. También el óleo, aplicando directamente el tubo a la tela, restregado por dedos y manos, hacía más intenso el diálogo con la figura finalmente encarnada.

Así, Obregón, en 1959, exhibirá en la Biblioteca Nacional de Bogotá sus veinte variaciones sobre el tema de los "Cóndores", donde todo lo anterior se percibe en una de las series más pujantes y más asociadas con su nombre, en el vigor incontenible de esa lucha de elementos, en el rectángulo del ave solitaria y la monumentalidad pétrea de las cordilleras. Sus fríos azules, el sismógrafo de los rayos blancos, la especie en extinción, que proclama por última vez el esplendor agonizante de su reinado.

A ello se añadieron, en 1960, sus "Volcanes", como su "Volcán submarino"; del mismo año, en amarillos, rojos y negros. Serie que intenta ser fiel a una naturaleza ya no solo colombiana, con el "Volcán de Galerazamba" (1967), sino que en sus orígenes mismos mira más allá de las fronteras como en su muy bello "El nacimiento de los Andes" (1961) con sus ya deslumbrantes soles amarillos hundiéndose al final de esas tierras marrones y rojas.
Cóndores y volcanes: unos al final de su existencia, otros recreando aún este continente de los siete colores, como lo llamó Germán Arciniegas.

Complementaría su fascinado interés por la naturaleza y el reino animal con las 26 témperas y crayones de su serie "La Mojarra", expuesta en la Librería Buchholz de Bogotá y las barracudas que iniciaría en 1963. Siluetas de ferocidad y movimiento que, en ocasiones en pequeño formato, cargan de furiosa energía la tela, con su ahínco para conjurar el despliegue visual con el afán de horadar la superficie mediante esa penetración cromática, ese drama de instante que apenas sí se alcanza a capturar y devora el momento en una fugacidad que es de todos modos recurrente. Volverán una y otra vez los cóndores, ahora convertidos en toro-cóndor, estallarán de nuevo los volcanes, entre zozobras y naufragios, y mojarras y barracudas, junto con las tintoreras, en renovadas bandadas que cruzarán cielos y mares, una y otra vez.

Solo que a las flores se unirán los mangles y se compactarán todos en sus jardines barrocos, de 1965 y 1966.

Este es el Obregón que en 1966 deja el óleo por el acrílico y que 
busca por las mismas fechas entonar su responso conmovido por lo que en forma horizontal llamaría "Huesos de mis bestias": adiós a seres que lo habían acompañado en sus exploraciones de un mismo tema, un mismo animal hasta diseccionarlo al límite, y convertirlo en un esquema comunicativo sobre el cual vuelve, hasta la extenuación.

En 1967 comenzará su serie de "Ícaros", donde insiste en un planteamiento que lo obsesiona como ya lo confirma su óleo de 1961, "Aves fulminadas por un rayo", que tiene algo de infantil diagrama, en colores claros.

Se dará la intersección entre ascenso y caída. El cruce de una libertad que se remonta y un poder que la derrumba y abate su fuerza. Por ello sus "Ícaros" tienen algo de ese drama ya tan cargado de referentes mitológicos, pero que también la naturaleza escenifica una y otra vez, como su "Fuga y muerte del alcatraz", un óleo de 1963, donde los espacios de color, gris azulado y blanco también compiten por establecer su dominio. A partir de 1968 sus series se desarrollan a partir de "Paisajes para ángeles", la versión prolongada, si se quiere, de sus "Ícaros", las “Anunciatas" de 1970 y en 1972 un gran cuadro para los museos del Vaticano con el título de "La Anunciación", de cinco por tres metros. Aquí la figura femenina hace su aparición reiterada, en diálogo desnudo y amoroso con el pintor, despejado el escenario y solo un eventual homenaje a Flora engalanará su frente y su cabello, mientras ella sentada se ofrece al deleite de la contemplación. Pero hay un duro contraste para esos sortilegios sensuales, en la playa a la orilla del mar. Son sus cuadros de 1973, denominados "Violada", donde una ancha franja negra en la parte inferior destaca aún más la expuesta colina del sexo de la mujer, ofrecida como una trémula herida. No hay rostro, no hay cuerpo. Solo el soporte de muslos y nalgas, en impúdica postura, como volteada sobre sí misma, en una mezcla atroz de deseo y crueldad. Todo se contempla desde atrás en piernas que brindan una torsión mecánica de maniquí, muy difícil de cicatrizar y recomponer, solo el sexo y su terrible herida violeta.

\section{Obregón: naturaleza y política}

Desde 1938, por lo menos, hasta su muerte en 1992, Obregón pintó sin desfallecer. Medio siglo de trajinar en pos de un lenguaje plástico. De 
intentar expresar una realidad que era evasiva y cambiante pero que a la vez tenía mucho de arcaica. "La línea ruda y el dibujo un tanto agresivo", dirá su colega Marco Ospina, refiriéndose a sus inicios, en 1948. Y en 1949 recalcará: "La aspereza de su estilo y lo sombrío de sus colores".

Eran quizás los empastes terrosos de mucha pintura europea de la época, en Francia y España, que luego de la indagación del cubismo, geometría personal, prismática descomposición, proseguía hacia la materialidad expresionista e informalista. Pero dos de las referencias de Obregón en aquellos tiempos tenían que ver con un español y un inglés: Clavé y Shuterland, de ningún modo ajenos al surrealismo.

Más entre retratos y autorretratos, con su saludo a Cézanne, manzanas negras o verdes, y líneas de fuga que enlazan copas y botellas, Obregón comienza a reconocerse en sus bodegones. A los cuales añadirá frutas y flores.

Era una mesa saturada de objetos, solitarios o acumulados en pirámide. A veces un tanto inermes y casi infantiles; en otras ocasiones, ya abarrotando el espacio. Allí pasará a limpio su diálogo con otros pintores, trátese de los perros y sandías de Rufino Tamayo (1947), trátese de Pablo Picasso en las tintas sobre papel donde esboza lo que sería su óleo "Masacre del 10 de abril" de 1948.

Tendríamos allí ya dos vertientes muy definidas de su tarea. La política, que lo hace reaccionar ante sucesos casi siempre trágicos de nuestra historia remota o próxima (de José Antonio Galán a Jorge Eliécer Gaitán para llegar al sacerdote-guerrillero Camilo Torres) donde la elegía se fusiona con la denuncia.

La otra veta se concentra en la recreación personal de la naturaleza, sea andina, caribe o amazónica, donde un lirismo cargado de energía no deja de promover una mitología propia, consciente, eso sí, de la tradición clásica. Pero también allí asoma un rechazo, con tintes ecológicos, ante tantos desmanes, como en su serie "Desastre en la ciénaga", de 1986.

La simpatía de la vieja guardia de la pintura colombiana (Luis Alberto Acuña, Ignacio Gómez Jaramillo) por su trabajo inicial, contrastará con el arribo al país, en 1954, de la crítica argentina Marta Traba, quien relegará a figuras como Pedro Nel Gómez, Sergio Trujillo, Carlos Correa, Gonzalo Ariza y los dos mencionados, para colocar en 
primer plano a Alejandro Obregón, quien en una foto del cronista visual de la época, Hernán Díaz, comparte con Eduardo Ramírez Villamizar, Enrique Grau, Fernando Botero, Armando Villegas y Guillermo Wiedemann, en 1960.

Dos escándalos célebres de aquel mismo 1960, como fueron la versión colombiana del premio Guggenheim y la representación colombiana a la Bienal de México, seleccionados ambos por Marta Traba, y rechazados por el grupo excluido que ella consideraba americanistas derivados de un muralismo mexicano ya un tanto exangüe, activaron la polémica. Quedaron bautizados, en caricaturas y panfletos, como los trabistas, con Alejandro Obregón como su profeta a la cabeza.

Pero dos cuadros de Alejandro Obregón contra la dictadura de Gustavo Rojas Pinilla (1953-1957), "Velorio para un estudiante muerto", de 1956, y "Luto para un estudiante muerto", 1957, mostraban lo que para usar los términos del existencialismo sartriano de la época, sería su compromiso. Algo que por cierto compartía con Jorge Gaitán Durán, el poeta director de Mito, quien en mayo de 1949 ya había publicado en El Tiempo un perspicaz análisis de su pintura, donde le reconocía "Cierto profundo y dramático espíritu colorístico, brotando como llama viva y naciente del suelo americano y desbordando la técnica europea".

Veremos en el primero de los cuadros mencionados sobre el estudiante muerto una apoteosis de rojos y amarillos donde el cuerpo tendido se ve acompañado por su ya consolidado alfabeto iconográfico: el gallo, la flor, la manzana, la botella, la sandía. El segundo se presenta como un sobrio esquema de luz y sombra, con su simbolismo de cruz y ataúd, de tintero y pluma, cerca de las tipográficas letras del alfabeto. Pero en el primero, el pie rojo y escindido del cuerpo y la barbilla amarilla que se tensa y se niega a morir del todo, nos confirman cómo los fragmentos del color y el andamiaje ortopédico que sostiene aún ese brazo también desprendido del tronco, nos llevan a pensar que el expresionismo figurativo de Obregón nunca rompió del todo con la armonía tradicional.

Trátese, más tarde, de la serie de la anunciación a María, un tema clásico si lo hubiere; o sus notables paisajes de Grecia, con su sabia luz otoñal y los muñones atemporales 
de templos y columnas. A lo cual debemos agregar su serie sobre Ícaro, caído luego del vuelo, con los dispersos restos de alas ofrecidos sobre una silla.

Pero hay otro mundo que Obregón intuye con olfato descubridor de nuevas geografías. Es su propio mundo colombiano, en la polaridad caribe-andino. Dinámica tensión de fondos sombríos cortados por relámpagos blancos de luz. Ásperas cimas de piedra e interminables lejanías marítimas o revueltos vórtices de crecientes súbitas del río. Así se desplegarán algunos de sus mejores momentos, en tres series: el cóndor, el toro y el ganado ahogándose en el Magdalena. Fusionados, en ocasiones, en un solo bloque. En un tótem erizado de huesos trágicos. De cuernos, picos y garras. Triángulos grises y rojos estallidos de sangre. Estética y violencia.

Y en los torbellinos del río, también pirámides de angustiosa agonía animal, vueltas severa pintura.

La naturaleza, quizás más que la política, reclamaría su atención hasta el final. El mar y sus aves, el mar y sus peces, el mar y sus naufragios. Toda una fauna que incluye iguanas y camaleones, búhos y chivos, mojarras, lebranches y apretados racimos de flores, con cuchillos y eclipses. Alcatraces y las siluetas históricas de las murallas de Cartagena de Indias con sus castillos y fantasmas, como la figura de quien convirtió en su antepasado: Blas de Lezo, el Teso.

Pero serán los volcanes del Quindío los que harán estallar su obra más emblemática: La violencia, de 1962. La mujer embarazada y apuñalada que ve cómo ha quedado clausurado todo horizonte por la barbarie animal. Será una época de muchas muertes y demasiados genocidios, cortes de corbata o de franela y fieras desatadas en el tortuoso entrelazamiento de formas agónicas, que van de bebés a irreconocibles amasijos, quizás en un momento humanos pero ya desfigurados del todo.

Quizás por ello volverá a los mangles del Caribe, a la Ciénaga Grande, donde fuera cazador, con sus entrelazados anillos vegetales y su palio de sombras. A sus jardines barrocos, como una compensación lírica ante tanta insensatez. Ya un bodegón de 1957: "Greguerías y un camaleón", nos recordaba esos estallidos de humor y poesía que Ramón Gómez de la Serna había sintetizado en aforismos llenos de ingenio. Sobre la mesa de Obregón había, cómo no, copas rotas, botellas de vidrio, el 
cuchillo, el camaleón y la roja y voluminosa fruta y el no dicho vuelo de la poesía que contribuye a levitar los objetos y los planos contrastantes de color.

Pero sus flores, qué remedio, se tornaban enfermas o carnívoras, y los mitos descendían a la tierra, trátese del aviador y novelista francés Antoine de Saint-Exupéry, correo aéreo en la Patagonia argentina. Solo que Obregón tenía los pies bien firmes, afincados en esa historia que va de Bachué a Bolívar y que le concedería, una vez más, la posibilidad de respirar libre, delante del lienzo, en la soledad de su estudio, desprendiéndose de la onerosa tierra, pesada de muertos, para alcanzar, en la agonía de todas las luces, los muy inalcanzables aires de la alta pintura.

En 1989 Leonel Estrada lo resumió bien:

Obregón es el precursor y el verdadero iniciador de la pintura moderna en Colombia. Crea formas, reinventa símbolos y todo esto sin caer en un oficio literario. Obregón reorganiza nuestra flora silvestre, se hace dueño del gesto para hablarnos en abstracto, pero regresa al lirismo para contarnos sin representar".

\section{Color expresivo}

La figura clave en relación con el color en el arte colombiano, el gran detonante, la gran luz y a la vez el más lento crepúsculo, sería Alejandro Obregón. El color de Obregón, primero al ólero, luego en acrílico, fue el encargado de armar y sostener su pintura. Fue la fusión de muchas atmósferas de Colombia, resultó un sismógrafo emotivo. El Caribe y los Andes, el río Magdalena y el Amazonas, las ciénagas y Barranquilla portuaria y abierta al mundo. Cartagena de Indias mirándose en el ensimismado espejo de su historia, antes de la prostitución vulgar del turismo. Era un color muy impregnado de naturaleza. En su esplendor jubiloso, en su gozo táctil. En el deleite de su larga pincelada que mezcla velocidad con fruición. Espíritu libre y sensual opulencia.

Registra un alba límpida y concluye, entre violetas y grises, en las más fúnebres y agónicas despedidas. En el medio, toda la paleta: amarillos y azules, verdes y rosas, marrones y violetas. Pero esa explosión electrizante se encauza y se desata en el soporte de una temática que tiene también algo de ráfaga submarina, de peces que son aves en vuelo por debajo del mar, de ángeles que se desploman grávidos por el peso 
mismo de la pintura y los muchos signos con que Obregón los circunda: velas, flores, flechas.

Voluta de ala, ascenso libre que luego se cierra en una suerte de círculo, de circunferencia de color, envolviéndose a sí misma en esos ocres, en esas tintas, donde percibimos la radiografía de un mangle, de un animal o insecto que ya es solo un postrer amasijo de vértebras dispersas, como sucedió con los "Huesos de mis bestias", de 1966. Lo que en su primera época era clara silueta, perfil definido, ahora se amalgama en un bloque horizontal que se consume a sí mismo entre franjas en negro y blanco. De fin de un ciclo.

Es curiosa tal trayectoria, porque la primera paleta de Obregón es apagada y terrosa, oscura en alguna forma, como su "Bodegón de la calavera”, de 1948, donde no pasa desapercibida la referencia a Ignacio Gómez Jaramillo. Pero ya en "Puertas y espacios", de 1951, cada objeto, cada fruta, vive su rigor geométrico con una fragmentación colorida de arte popular. De cerámica mexicana, por denominarla de algún modo.

Todo ello daría origen más tarde a esos colores que ya parecen consustanciales con Obregón: el rojo de la violencia y el gris de la agonía.
El último Obregón, que con el acrílico había dado a sus cuadros algo estridente y cinematográfico, de eclosión decorativa, como no dejaron de señalar varios comentaristas como Antonio Caballero o Germán Rubiano, requería ese fondo de grises, de penumbra y sosiego, para instalar allí su gramática de puntos, hojas, enlaces y medialunas.

El óleo le otorgó base y materia, le dio sustento y solidez, a quien se enfrentaba a grandes desafíos, llámese Cotopaxi o Chimborazo, y el acrílico le dio agilidad, penetración y vibrante rapidez, para captar tanto un colibrí como el punto en que el alcatraz se hunde en la lámina del mar. Pero el resultado bien puede ser el resplandor que emana de un blanco plomizo, la conflagración que suscitan esas ondulaciones cromáticas. A veces apagadas. A veces estremecidas. De los tonos sordos y ocres a una visión más luminosa y brillante. De la estructura geométrica hacia una paulatina espontaneidad expresionista.

Porque en Obregón, no lo olvidemos, hay también, como en el caso de óleo-acrílico, otra dualidad que resulta suscitadora y estimulante: una propensión épica y una inclinación más inmediata y cotidiana. 
Piénsese en el "Amanecer de los Andes", de 1959, donde ave, roca y montañas vuelven aún más desmesurada su silueta, gracias al contraste de su negrura con el delicado rosa de la aurora, que no hace más que acrecentar el poderío de sus patas o la voluta barroca de su collar de plumas blancas en el cuello. Algo similar por cierto a "Blas de Lezo (autorretrato)", de 1979, donde las plumas blancas ya están en su propia cabeza, de bigotes, patillas y un solo ojo azul, premonición de su propia pérdida de visión, en el ya apagado marrón del fondo cruzado apenas por un reborde rojo. Ya es solo él mismo, despojado de lo que no sea la misma pintura.

En el ámbito que denominé de lo cotidiano están las seis hojas de su "Silueta", un óleo de 1948, o la "Paloma" de una década después, o las "Aves fulminadas por un rayo" de 1961. "No hay que pintar temas, sino emociones", dijo en alguna ocasión, y quizás por ello muchos de sus cuadros no le temen ni a la zozobra ni al naufragio. Los asume en el silencio sensitivo donde aprendió a escuchar la poderosa y abigarrada voz de la naturaleza y el mudo milagro con que la figura humana se imponía como un enigma, tal como él mismo, en el "Dédalo", de 1985, se representó, perplejo y asustado, con las manos vacías, antes de penetrar en el último laberinto.

\section{Un retrato}

La pintura era una forma de exaltar la vida. De celebrarla en colores. Pero la pintura era también una larga agonía. Un dilatado crepúsculo. Por ello sus colores emblemáticos siguen siendo el gris y el rojo.

Su personalidad era afirmativa: rotunda, viril. Pero las perplejidades, las dudas, los silencios, también eran parte esencial de su carácter.

Pertenecia a una familia de recursos, en un país de pobres irredimibles. Pero había optado por un oficio que lo colocaba en el azaroso mundo de la bohemia. De la marginalidad asumida. ¿Qué significaba ser pintor en la Colombia de entonces? Poca cosa: retratos académicos, algún encargo público. Solo su generación vio establecerse las primeras galerías comerciales. La continuidad de los salones nacionales. El refugio de las escuelas de artes.

Defendió su opción, con coraje, y muy pronto fue reconocido. Se había educado en el exterior: España, Inglaterra, Estados Unidos, pero fue un feliz autodidacta, en definitiva. 
Pintó retratos de señoras con apellido y había llegado a ser tan vicecónsul (ad honorem) en Barcelona como director de la Escuela de Bellas Artes en Bogotá. Pero lo decisivo fue la configuración de un mundo propio. Por fin un colombiano incorporaba la furiosa eclosión de una naturaleza feraz al marco de una decantada asimilación plástica. El mundo de Cézanne, el mundo de Picasso, de sus colegas latinoamericanos, ávidos de impregnar el lienzo con la materia y los símbolos de un continente que se desperezaba del sufrido poncho indígena.

No estaba solo: allí cerca vivían Tamayo, Lam, Matta, Szyslo. Su obra, en Colombia, trajo el estimulante aire de una libertad imaginativa. Ese bodegón que cultivó toda su vida, donde la escueta mesa horizonte le permitía disponer, en compartimentación rígida primero, luego con énfasis gestual, el reiterado repertorio de toda su vida. Una copa, una patilla, un mangle, una iguana, una flor carnívora, una mojarra, un alcatraz, una barracuda, un gallo, una paloma, un chivo.

Formas que se ensamblaban o se fundían, que se entrelazaban o permanecían aisladas y a las cuales esas flechas, esas letras, esas ráfagas terminaban por otorgarle hondura o dinamismo. La frágil voluta de la poesía. La rúbrica estremecida de la muerte misma,

Pero esos motivos clásicos, por así decirlo, eran heridos por el rayo inmisericorde de la violencia. El cuerpo del estudiante tasajeado sobre la consabida mesa. El paisaje agónico de la mujer preñada. El cielo oscuro rasgado por un trueno de luz.

Parecía querer estar allí donde sucedían las cosas: el 9 de abril, el 10 de mayo, la caída del avión donde moría su amigo Gaitán Durán. El Che, Camilo, el asesinato de Gloria Lara. Pero el reverso de este rostro público de participación y denuncia era su conventual estudio de Cartagena de Indias. Su anterior cuarto de altos techos en la calle de San Blas en Barranquilla. Se aislaba para escuchar mejor la algarabía del mundo.

Siempre los amigos, cena, farra, burdel o casino, y siempre la soledad de quien se había casado cuatro veces y pintaba orgulloso sus hermosos hijos. Siempre, también, el devorar de nuevo el mundo tras la secreta, incitante, misteriosa conquista: la modelo, la esposa del político, la mujer del primo. Qué crónica exaltada la de este caballero solo, en un país de hipócritas 
tartufos. Su misión por cierto no era la de escandalizar, sino la de pintar. Pero su fraterna relación con los poderosos de este parroquial mundo, de millonarios a toreros, lo situaba en una vorágine contradictoria de figura pública y de sigiloso lector de poesía. De trasnochador festivo y obrero riguroso en el límpido amanecer del otro día.

Era intuitivo, amante de los azares del destino, pero era también un guerrero que combatía su espantoso miedo íntimo, liándose a puños o enfrentándose a una vaquillona en una corrida. Al lado de Marlon Brando, en Quemada y con uniforme de militar napoleónico, podía sentirse por fín a gusto.

Riesgo, coraje, valentía, que se tradujo muy pronto en la dimensión épica de su pintura: los toros, los cóndores, las blancas cimas de las cumbres andinas, el ígneo cráter de los volcanes, el vértigo de esos ciclones del Caribe borrando de la tierra las vanas pretensiones de los hombres por domesticar un trópico que todo lo consume, exigiendo su refundación perpetua cada día.

Así concibió los vientos azules de Jerónimo Bosco como algo desmedido que increpaba al mundo, $y$ así logró que varios de sus cuadros más enigmáticos y profundos nos hablen del mar y sus abismos, de la geología marina, de islas que surgen de súbito en las tinieblas del génesis, donde la luz es aún oscuridad maciza.

El vislumbrar, en un parpadeo, esa claridad que fulge y a la vez se extingue. El resquicio por donde quizas Antoine de Saint-Exupéry escapa de sí mismo, correo por la planicie patagónica o piloto militar en la guerra aérea donde los cazas alemanes poblaban el cielo con estrellas mortales.

Obregón nacía con el impulso y quería vencer con la pintura el intolerable límite. Pero todo terminaba por referirlo al esplendor voraz de la naturaleza misma: la vastedad de los ríos amazónicos, la descompuesta rabia cuando comprobó en 1986, el desastre de la Ciénaga Grande. Algunos imbéciles, por estupidez o lucro, la habían escindido de su mar nutricio. La carretera seguramente sería muy útil, pero el caos de peces muertos, de aves sin donde sembrar sus nidos, de tierras anegadas y árboles podridos, por años, lo descompuso. Allí estaban sus fúnebres azules, sus iracundas naranjas, para sentar su protesta. Había que gritar, de vez en cuando, aun cuando 
él prefería, cómo no, el sigiloso silencio de una pincelada tersa y expresiva. La dilatada perspectiva de un drama de cielo y tierra, de luces y nubes. Pero había que dejar la protesta escrita y referirla, de algún modo, a la lección del mito. Si un ángel caía era de nuevo Ícaro al intentar sobrepasar lo imposible.

Así funcionaba la mente de un pintor, que sabía mucho de pintura y no hablaba nunca de ella, y que se debatía entre el reclamo diario de las cosas de este mundo y su afán de consignar un testimonio no solo de crítica, sino de perdurable concreción estética. De belleza que subsiste. Fiel a sí mismo, Obregón, al hablar de las acuarelas de su amigo Hernando Lemaitre, expresó dos de las grandes verdades que están en la base de su arte:

"La naturaleza fue creada casi exclusivamente para ser pintada", y "El arte, además, sirve para vivir después de morir".

No lo olvidemos, al visitar el territorio casi inabarcable de su pintura.

\section{II}

Obregón amaba avionetas y lanchas, un jeep destartalado que exigía al máximo, la camioneta en cuya guantera Álvaro Cepeda dejó olvidados los primeros manuscritos de La casa grande. La velocidad con que la visión se despliega y refresca la rutina. El quemar etapas como quien lleva sobre sí la carga de sus muertos y los huesos de sus bestias y debe, cada día, saludar al sol con la sorpresa de un niño. Cuando expuso en Caracas, en el Centro Cultural Consolidado, la exposición tenía un título desmesurado: "Obras Maestras" y un subtítulo inquietante: 1941-1991. Medio siglo de bregar con los tubos y las brochas. De trajinar con las telas y los marcos. De decir algo propio, a través de esos objetos-símbolos, de esas formaslenguaje, que era necesario profundizar y renovar. Retomar, una y otra vez, y deshacer, en una nueva metamorfosis.

Tenía, en primer lugar, que ir más allá del esmirriado panorama que encontró. Toda esa pintura quieta de los paisajistas de la Sabana, con sus aposentadas aguas en medio de inmóviles árboles y pétreas vacas. Todos esos acuarelistas antioqueños de bucólico idilio y raza recia, desmontando selva. Toda esa pintura de los Bachués con sus puntillistas mitologías indígenas, más propias de la antropología que de la identificación 
emotiva: ¿Qué nos dice Bachué, que nos dice Bochica, la diosa y el dios? Muy poca cosa. Todo ese arte social para un país campesino que nunca conoció reforma agraria. Toda esa industrialización incipiente, con fábricas y chimeneas, que plagiaba el muralismo mexicano y veía cómo el aparente progreso arrastraba su cauda inexorable de marginalidad y pobreza.

A todo ello Obregón dijo NO y puso sobre la mesa la elongada silueta de un único y solitario pez dorado.

Había que partir de cero y volver al origen. Como decía Roberto Matta con gracia: "Agitar el ojo antes de mirar". De ahí ese expresionismo luminoso y vibrante que nunca fue abstracto: se trataba de una niña con un pez en la cabeza, del mismo dios Neptuno emergiendo del mar, de los jardines barrocos apelmazados de signos. Siempre se intuyen detrás las poderosas fuerzas de la naturaleza, recordándonos el punto de partida. Igual sucedía al decretar su extinción. El riguroso apocalípsis de su último cóndor, de 1981, se fundía dentro del sombrío esplendor de sus calcinadas plumas. Pero no desaperecía del todo: resucitaba. Resurgía en el estallido cromático del acrílico. El desgastado símbolo se transformó en pujante pintura. Le había conferido renovada vida.

Era el pintor emotivo que empezaba a encontrar, para Colombia, un museo imaginario de figuras propias. Un lenguaje y un estilo: el del entrecruzado diálogo de la costa con el interior. De la cordillera con el mar. De los centenares de vientos, de la galerna a la tramontana, con la transparencia mágica de atmósferas hasta entonces inconcebibles por su virtuosismo de brochazos dilatados y soberbios.

La controlada ambición de un gran pintor. En ello lo acompañaban la cohorte espléndida de sus amigos de generación: Gabriel García Márquez, Álvaro Cepeda Samudio, Álvaro Mutis, Alfonso Fuenmayor, cronista inicial de su grupo. Trataban de encontrar una fusión entre su desmadre vital y el rigor de la tarea artística. Los nutría un contorno de ciénagas y cacerías, de cantinas y burdeles, de participación cívica y presencia pública en murales, libros, premios de novela, revistas, salones nacionales e internacionales, y el mecenazgo de empresas nacionales y grupos financieros que así veían exonerados sus pecados capitalistas con algún renglón de 
sus presupuestos de relaciones públicas destinados a la cultura. Álvaro Mutis lo hizo desde ESSO como Álvaro Cepeda Samudio desde Bavaria, mientras que Gabriel García Márquez, Germán Vargas y Alfonso Fuenmayor abrían aún más el espacio desde las páginas de los periódicos.

Además, el ir y venir, el estar en la costa caribe, le permitía disfrutar una frontera natural, donde el influjo de Estados Unidos se remansaba y se hacía propio, gracias a una ya centenaria cultura triétnica, de leyendas del río Magdalena, como el hombre caimán, y del desafuero del carnaval de Barranquilla y el entierro de Joselito, que bien podía matar también amigos como el pintor "Figurita", inmortalizado en otro cuadro suyo.

No necesitaban del respaldo de la Unesco para saber lo importante que era: el ron, la música, los gorros de los congos, las comparsas histriónicas, eran, por decirlo así, confirmación de un gran estrato cultural que los alimentaba y obligaba a preguntarse, creativamente, por su sentido. De igual modo, el flujo de visitantes extranjeros, del mexicano Juan García Ponce al cubano José Gómez Sicre; de la argentina
Marta Traba, novia en algún momento de Cepeda Samudio, al norteamericano Tom Messer, quien incluyó a Obregón en una célebre exposición de 1965 titulada "La década emergente", aireaban aún más sus propuestas, en exigente diálogo con sus pares de otros países. No estaban ensimismados en las facciosas rencillas del interior. El pintor ilustraba los cuentos del novelista amigo o padecía, con risas, cómo este le robaba la anécdota de su última hazaña de pescador de sábalos ... o de muertos.

Así era. El arte se imbricaba con el tejido social pero era ante todo una aventura individual por excelencia. Sin prerrogativas, por cierto, pero también sin manoseos. Establecieron con ese medio siglo de entrega sin concesiones una renovada escala de valores: había que respetar el trabajo del artista (y pagarlo bien) porque sin el artista un país resultaba literalmente incomprensible. Carecía de memoria, de rasgos propios, de un presente de convivencia y compartidos modos de sentir y de pensar. Todo ese proceso de conformación, en definitiva, de una cultura más plural y más rica, menos tortuosamente represiva y política, puede seguirse en las 
felices páginas de las notas de prensa de García Márquez como su bello texto: "Obregón, o la vocación desaforada” o de las novelas de Álvaro Mutis, donde Alejandro Obregón ha quedado reflejado como un ser creativo y torrencial, en el arte y en la vida. En la ya mitológica saga de su intensidad sin reticencias.

Pero a la vez qué pudorosa cautela la de su ademán fraterno. Qué fino tacto para seducir y acompañar, con fuerza y delicadeza. Para proteger y establecer claras distancias. Para disfrutar y hacerse respetar, en un país muy dado a la promiscua chabacanería y al imperio ya desde entonces visible de los medios de comunicación como vehículos del chisme y la nivelación por lo bajo. La ignorancia, que como decían las abuelas, sigue siendo atrevida.

Todo ello de un sutil modo indirecto, ha quedado reflejado en su pintura. En el poder que emana de la presencia misma, trátese de la "Nube gris", de 1948, como de su "Autorretrato (astigmatismo)", de 1949. El ser, la figura en sí, está allí recordándonos el poder avasallante de su magnetismo. Pero a la vez esa irrupción ineludible en nuestro campo visual tendrá también un aura de misterio, una proyección sugerente en las asociaciones infantiles, un caballito de bronce, o en el misterio inquietante que emana de los objetos más cotidianos: un cuchillo. Un gato. Una cartilla. Un camaleón. Sí: todo se hizo para ser pintado. Incluso él mismo.

Por ello se involucró de modo tan estrecho en su serie sobre Blas de Lezo. Tan herido como él, tuerto, manco y cojo, y tan capaz de ir más allá de él, para seguir pintando. La ceguera de sus postrimerías parecía el precio que los dioses celosos cobraban a quien había velado el rostro de sus mujeres, deslumbrado por el resplandor intolerable de todos los seres. Una cultura santurrona, de editorial y discurso, era ahora fraterna y emotiva. Sus aves, como las aves finales de Braque, se apoderaron no solo de su estudio: presidían el Consejo de Ministros, en el Palacio Presidencial, o las paredes del Congreso de la República, dándole un más renovado aire a ese país que tantas veces puso en duda en masacres, asesinatos y feroces "Muerte a la bestia humana". Por ello una palabra secreta, que empleó pocas veces, "concordancia", nos confirma cuánto de sí mismo hay en su arte, con honesta empatía, y cuánto de su arte está en nosotros, como piedad, 
consuelo y fuerza regeneradora y altiva. Disfrute y regocijo artístico.

\section{Retrato literario de Alejandro Obregón}

Llegó elástico a la casa de Feliza Bursztyn, con ese vaivén de marinero en tierra o tigre en suspenso que lo caracterizaba. Era como si tuviese electricidad en la planta de los pies. Besó cariñoso a Feliza, niña perdida en el bosque, y con un bronco "Hola, Juan", lanzó su ancha mano, de vello rojo. La misma que por aquellas fechas, 1974, había engalanado el cielo de la pintura colombiana con la sutileza de sus grises y la enhiesta presencia inmóvil de sus cóndores.

La casa-taller-escalera de Feliza era la mejor universidad del mundo. En ella Fernando Martínez Sanabria y Hernando Santos proponían quemar El Tiempo, Hernando Valencia Goelkel canjeaba viejos números del New Yorker con Alicia Baraibar y Gabriel García Márquez despachaba asuntos editoriales y enhebraba sus conspiraciones internacionales desde la mesa del comedor.

Tal galaxia de astros giraba en torno a los bellos huesos de Feliza y a la figura de Alejandro, que pasaba como un cometa incandescente desde su remoto reino de Cartagena.
La madre llamó, la madre se emborrachó, la madre inaugura, la madre viene el jueves: así lo designaba Feliza, heraldo feliz, y la presencia de Alejandro era como el arribo del sol en medio de los melindrosos fríos bogotanos.

También viejos y nuevos amores terminaban por ser, todas, confidentes de Feliza, quien las pastoreaba en la desilusión y las acompañaba en la ausencia. Pero caballero, Obregón continuaba siendo gentil, hasta el fin, y más allá de él, con todas ellas.

Aquel día acababan de pagarle una barbaridad de muchos ceros por algún cuadro y se reía del cheque, arrugado, manchado y de seguro incobrable. Pero estos solo eran gajes del oficio. Lo importante eran los grandes vasos llenos de alcohol que Feliza, hada madrina, jamás dejaba vacíos, y las inverosímiles sopas de lenteja que Feliza distribuía, más como reconstituyente para seguir la charla que como aportes a la gastronomía.

La charla de Alejandro era una feliz derivación del género aforístico: frases-centellas. Imágenes vibrantes que ahondaban el silencio en torno a la pintura, al llevarnos de sorpresa en sorpresa. Por aquellos días escribía el primero de los muchos textos 
que dediqué a su obra, con motivo de su retrospectiva "Aire, mar, paisaje, diálogo", y lo que más le gustaba, con razón, era una cita. Aquella que Lezama Lima toma del Perugino. Se acercó a su ayudante y le dijo: "Prepara la sopa, mientras tanto voy a pintar un ángel más".

Alejandro estaba encantado: la pintura también era cocina. Llevar adentro el tema y dejarlo hervir, durante mucho tiempo, hasta que llegue a su punto de cocción. Calor y frialdad compaginándose, como el Caribe y los Andes. Y la sal marina con su pellizco de azúcar, escondido bien adentro.

Esos dos extremos de Colombia que él supo conjugar mejor que nadie, ya que su pintura resulta ahora la gran conciliadora. El diálogo que nos hacía falta. La brutal explosión de la sangre y la cariñosa delicadeza de los pequeños detalles: una araña, una lechuza, un gato. O los rostros desnudos, en su límpida inocencia, de sus hijos. El maestro del paisaje se contenía, firme en su ternura, ante el arrasador milagro de la eterna fragilidad humana.

Tenía el poder necesario para resistir las cautelosas mezquindades y el arrojo suicida para poner en duda toda la gloria que ya pesaba sobre sus hombros. Qué orgullo para Colombia tener como pintor oficial a un iconoclasta de alma. Un hombre alerta, en el filo de la navaja. Aquel día, cuando lo conocí, no se detuvo: nos llevó a un recorrido alucinante, por la sórdida noche bogotana, redimido, al final, en plena madrugada en el Parque Nacional, al recitar poemas de Keats, en inglés, como presagio del alba. O contando anécdotas sobre Chaliapin, el cantante ruso.

Luego, desayuno de huevos pericos con coñac donde una amiga, Asenet Velásquez y ahí volver a empezar, como si la fatiga, controlada por la intuición y la poesía, no fuese obstáculo para el esplendor inagotable de la amistad recién iniciada. El tímido Alejandro, rotundo al proclamar su pudor, sin pena ni atenuantes.

Tenía el orgullo bien plantado, y no se dejaba manosear, pero la gentileza de espíritu lo mantenía erguido, comprendiendo y olvidando. Ahora lo veo acompañándome por las galerías del Museo del Prado y diciendo “ $i Q u e ́$ bestia!" o “¡Vaya cojones!” ante cualquier escorzo del sordo Goya. No hay duda, era un pintor. Veía todo con hambre de luz y los colores, que en ocasiones 
estallan excesivos, o las composiciones que parecen desfallecer, bajo tantas figuras emblemáticas, resaltan apenas su desesperado afán de indagar sobre el enigma evasivo, en grande o en pequeño formato. Lo aureolaba el viento del Caribe y sobre su horizonte, siempre en fuga, volvían a crecer las montañas, a remontar vuelo los cóndores y los toros, las tintoreras y las arpías, y a extenderse las patas de los chivos expiatorios.

Su pintura, como toda auténtica pintura, era forma, y no autobiografía. La impregnaba con su vida, la rellenaba con sus seres queridos, protestaba o blasfemaba con ella, impotente ante tanto crimen, pero ahora, vista en conjunto, parece ordenarse en torno a un solo núcleo: la mesa que luego fue cielo y sobre la cual desplegó el bodegón infinito de una naturaleza tropical bien viva. Como los cuernos en pugna de su "Ganado ahogándose en el Magdalena" (1955) o su "Ícaro calcinado" (1967) de una década más tarde, su metáfora central era siempre la misma: hundirse y renacer.

Quemarse, para así estar vivo, orgulloso de la caída y sus cicatrices. Como los viejos donantes de los trípticos medievales, su actitud era la de la ofrenda. Exaltar las cosas para que no mueran. Y luego sí, como en los "Huesos de sus bestias", destruirlas para que no se congelen en una fórmula. Cuán difícil resulta escapar de nosotros mismos y saltar sobre nuestra sombra.

Pero él lo intentaba cada día, con cada boceto y cada nuevo cuadro. Puso a prueba nuestra mirada, enseñándonos el auténtico riesgo que encierra toda verdadera pintura. Pero él, no hay duda, prefería otro trago, antes que hablar tanto.

Si bien su obra sigue fluyendo a través de las sucesivas miradas que la redescubren, cada día, quienes no conocieron a Alejandro Obregón valorarán su pintura lejos del fascinante clima de sugestión personal, gracias al cual otorgaba trascendencia al más nimio de los gestos.

Encontrarán allí una poderosa mitología plástica pero no podrán dilatar ese encuentro con la propia palabra del maestro, a la vez reticente y aguda. La misma que siempre sugería un más allá inexhausto: una luna negra en cuarto menguante, besándose con un sol dulcificado por esa luz, aún no tibia del todo, de las siete de la mañana. Tales sus metáforas para mantener vivo el deseo. 
Por ello quizás siempre estuvo cerca del mundo de los novelistas y poetas, como lo atestigua el famoso prólogo al libro de Álvaro Cepeda Samudio: Los cuentos de Juana (1972), en el cual Cepeda entrevista a Obregón para terminar Cepeda siendo entrevistado por Obregón.

Había algo muy literario no solo en su pintura, sino en la filosofía de su vida vista como una aventura heroica, compartida con los amigos como una jornada deslumbrante, de la adolescencia al ocaso. Como lo dice Obregón Cepeda en el citado prólogo:

"La complicidad en este caso particular significa otra cosa que la gente no sabe, ni siquiera sospecha. Significa ternura, respeto, discreción a gritos, amor a rajatabla y todo lo demás que solo está al alcance de los que viven a flor de piel".

Desde allí era de donde estallaba su palabra y por ello trazaba, sobre papeles arrugados, esas frases que hoy son legado y decálogo. Inscripciones para que el tiempo no desaparezca en vano. "En arte lo bueno no sirve, ni siquiera sirve lo excelente. Hay que llegar a lo improbable".

Pienso ahora en cómo ese hombre, eje cálido de una vasta tribu familiar y a la vez aureolado por la soledad obsesiva de su oficio, llegó a convertirse en la figura central del arte colombiano. Si León de Greiff es el poeta por antonomasia, Alejandro Obregón es el pintor por definición.

Le aburría, de seguro, exponerse, no sólo a través de sus cuadros, pero estaba allí donde fuese necesario, firme al pie del cañón. Firmaba el manifiesto del 8 de mayo de 1957, en el cual los intelectuales repudiaban la dictadura del general Gustavo Rojas Pinilla, y poco antes de morir protestaba, ecológico, contra las matanzas de flora y fauna en la Ciénaga Grande. Todo ello sin descuidar al pintor incipiente que respaldaba en su primera muestra o al asumir la dirección de la Escuela de Bellas Artes, cuando acompañó a los jóvenes en su rebelión contra el academicismo.

Como si la pintura fuese arma y bandera, y ella misma le hubiese otorgado el pleno derecho para sentirse bien instalado en la celda y en la plaza, en la revista frívola o en el sofocante estudio de televisión. En todas partes lucía la misma entereza y a la vez lo élitros de una sensibilidad que se orientaba, con sagaz olfato, por entre los pliegues de las olas, 
las inclinaciones de los vientos y el flujo y reflujo de esas grandes masas marinas que dominan, no hay duda, las tres cuartas partes de la superficie del mundo y vuelven aún más frágil esta precaria tierra que con razón pisaba como cubierta de barco, en medio de la zozobra.

Zozobra, me consta, una de las palabras que más amaba. Allí, en ese intersticio, entre la sombra y la luz, él clavaba un color, sugería un mundo. Sus mejores momentos, por ello, son el amanecer eléctrico y el crepúsculo dilatado, en grises y rojos agonizantes. Todo visto desde la terraza árabe de su casa, en Cartagena de Indias. Álvaro Mutis lo captó, mejor que nadie, en su Tríptico de mar y tierra (1993), cuando fue más allá de la figura y se internó en la profundidad imposible de su tarea:

él sueña con pintar un día la vida, no la diaria y necia rutina de los hombres, sino la vida, la de verdad, la que solo encuentra respuesta en la mudez rotunda de la muerte. Ese propósito no se le cumplirá nunca, pero jamás alguien como él aceptaría una derrota semejante. Allí dejará Obregón la piel, pero no va a cejar. Usted bien sabe que es así. La vida se nos viene encima como una bestia ciega. Se traga el tiempo, los años de nuestra existencia, pasa como un tifón y nada deja. $\mathrm{Ni}$ la memoria siquiera, porque la memoria está hecha de la misma sustancia inasible y veloz con la que surgen los espejismos y luego desaparecen. Y cómo va alguien a lograr pintar algo así (p. 92).

Lo grave es que Obregón lo logró. Me alegra comprobarlo cuando leo lo que un crítico, Fernando Quiroz, dice refiriéndose a los nuevos pintores colombianos, nacidos todos ellos después de 1950. En Nueva Imagen (1994) y al hablar de la "resurrección del color" anota Quiroz el énfasis en sensibilidad, vivencia y transmisión expresiva de sentimiento, como rasgos (obregonianos, diría yo), de la más reciente generación.

Un buen síntoma de que su legado se renueva y su tarea no se torna inválida. Solo que su lección mayor no era únicamente la del color o la forma, sino la de ser como era. Como lo dijo Feliza: "No nos importa que pinte: nos basta con que exista".

\section{La realidad transfigurada}

A Alejandro Obregón le preguntó José María Salvador de qué pintor creía tener alguna influencia. "Tamayo, Wifredo Lam, Matta, Picasso", desde luego ... Todo el mundo tiene algo de la impertinencia de Picasso. Esta fue la respuesta. 
Muy razonable por cierto, ya que Rufino Tamayo, en un reportaje de 1959 con Víctor Alba aparecido en el No. 14 de la revista Plástica, de Bogotá, había señalado dos puntos decisivos en relación con la pintura moderna. Su propósito, en primer lugar, para "capturar el tiempo en la tela", y en segundo lugar el objetivo de dejar atrás la visión deshumanizada del arte para dar paso "a una vuelta a la poesía y a la imaginación que son las bases mismas del arte plástico".

Afirmaciones muy afines al pensamiento de Obregón. Y al de un cercano compañero generacional, el peruano Fernando de Szyszlo, quien en su texto "La pintura latinoamericana contemporánea", de 1960, recalcaba uno de los fines básicos del periodo, y en especial de este grupo: "crear un arte que siendo universal tenga raíces propias" $\mathrm{y}$ que en la relación con la pintura que se hacía entonces en América Latina tenía delante suyo tres líneas de trabajo: la realidad transfigurada, la abstracción geométrica y la abstracción lírica. Lo que Carlos Mérida señalaba como "la transmutación de la realidad a organismo plástico". $\mathrm{Al}$ anunciar, en 1957, lo mismo que escucharíamos de Tamayo dos años más tarde: "Tengo la ambición de hacer pintura poética porque creo que no hay arte sin poesía. Todo apuntaba en el mismo sentido: captar la secreta poesía de un continente y expresarla mediante el lenguaje ya conformado del arte contemporáneo, llámese cubismo, expresionismo, surrealismo. "Ruptura con toda sujeción de la expresión artística a los modelos de la naturaleza", como indicó Wilhem Worringer.

Pero el propósito básico de Alejandro Obregón era instalarse en el centro de una naturaleza, que había vivido en las selvas del Catatumbo, cuando fue camionero y traductor, o de las ciénagas por las que andaba, con el agua a la cintura, en las épocas en que era cazador, con sus amigos de La Cueva, ante todo taberna de cazadores para beber después de la jornada.

Todo lo suyo estaba impregnado por esa vivencia de la naturaleza: sea el cóndor enjaulado de la Universidad Nacional, sea el alcatraz herido que le trajeron y que cuidó seis meses, lo que expresó al decir: "Hay que tener la sensitividad de un toro y la fuerza de una mariposa": la naturaleza, ya subjetivizada.

Quien estudia en Inglaterra y Estados Unidos, vive cuatro años en 
Barcelona y otros tanto en Francia, se caracterizará por su vinculación profunda a Colombia, ya sea como profesor, director de la Escuela de Bellas Artes en Bogotá (1948) y, más tarde, en 1962, decano de la Escuela de Pintura de la Universidad del Atlántico, organizador de muestras colectivas de pintura, como el Salón de los XXVI, en 1948, en el Museo Nacional, y director del Movimiento Nacional de Artes Plásticas (MNAP), en 1955.

Todo lo cual nos lleva a pensar en un activismo acorde con su vocación de pintor volcado hacia una búsqueda de lo colombiano, primero, y más tarde lo americano, como bien pueden ser los rituales indígenas del Alto Perú, con el cóndor precolombino amarrado al toro hispánico, en combate de civilizaciones, sustentado, en cierta forma, en su experiencia personal de gran aficionado a los toros y amigo muy cercano de la dinastía española de los diestros Dominguín. Que un célebre texto de Ernest Hemingway reflejaría en el duelo Luis Miguel Dominguín-Antonio Ordóñez. Esta cargada experiencia vital, camionero, cazador, novillero, se iría decantando en una pintura que busca perfilar los símbolos, por ejemplo, de una Barranquilla donde el "Entierro de Joselito Carnaval" (1957) y las comparsas con máscaras de toro y botellas de ron en la mano, la danza del torito, terminarían por ser, un año más tarde, el "Homenaje a Figurita”, pintor muerto en la desatada euforia del desfile de comparsas. Algo que resumirá la silenciosa trompeta ya sin música. Este compartido conocimiento vivencial de una cultura popular de fiesta y barrio, de pueblo expresándose en mitologías propias en el que intentará simbolizar, en muchos casos, en la misma forma en que Lam en Cuba o Tamayo en México ahondan en sus tradiciones ancestrales, indígenas o negras, y extraen de allí síntesis y arquetipos de gran expresividad, con marcado acento personal y a la vez colectivo.

Algo sobre lo cual Alejandro Obregón volverá, en 1978, en su serie Bachué. Donde la mitología índigena chibcha, es ya sólo un desnudo cuerpo de mujer sin rostro, oculto en la penumbra, con sus rituales búhos y esa apretada caligrafía de flechas y flores, sugiriéndonos la oculta atracción del misterio. De ese mundo precolombino que no sería preocupación básica suya pero que no dejaría de tomar en cuenta, como 
la leyenda del hombre caimán, que disfrazado, seduce muchachas a la orilla del río Magdalena. Todo era un buen pretexto para pintar. Para sentirse partícipe en la consolidación de una nueva mirada. De una revitalizada cultura visual.

\section{Las décadas finales}

El reconocimiento a Obregón es ya unánime. Esto se refleja en muchos encargos para murales, que lo llevan a proseguir en un arte que ya había dado su "Simbología de Barranquilla”, en 1956, con sus anclas, tenazas, martillos y botellas, además de los peces-pájaros y el rostro de la muchacha con aire de princesa indígena, en su habitual mosaico de recuadros.

En 1973 pintará para el Banco de Colombia, en Bogotá, en la Plaza San Martín, un cuadro-homenaje al poeta José Asunción Silva, que llamará "Sombra larga y música de días". Amplios trazos para hacer aún más vasto el espacio en que respiran los versos del poeta y su al final trágica vida.

En 1982 el mural marino que llamará "Galerna" para el Centro de Convenciones de Cartagena, al cual añadirá el año siguiente el telón de boca para el teatro Amira de la Rosa, en Barranquilla, con el tema del hombre-caimán. En el mismo 1983 presentará en el Salón de Delegados en las Naciones Unidas, en Nueva York, su "Amanecer en los Andes", que inagurará el presidente Belisario Betancur. Quien también dispondrá, en 1984, de una sala especial para su obra en el Museo Nacional. Finalmente, en el Salón Elíptico del Capitolio Nacional un vasto mural, "Victoria de tres cordilleras y dos océanos", que lo convierten en el pintor colombiano de referencia ante cada nueva ley, ante cada nuevo debate parlamentario por televisión. Allí están las puntas de las tres cordilleras, en sus grises, y el carrusel incesante, como la historia, en que peces y aves se cruzan en sentido contrario, con sus azules, verdes y amarillos.

Quizás volvía a recordar uno de sus aforismos: "El arte sirve para todo, salvo para resolver problemas", cuando realizó, afectado y furioso, los 32 cuadros sobre madera, que tituló "Desastre de la Ciénaga de la Virgen", de 1986, nueve de los cuales se reunirán en su catálogo Cinco décadas, correspondiente a sus exhibiciones en Monterrey y en Ciudad de México. Si la naturaleza lo había nutrido artísticamente toda la vida, 
ahora era necesario dar la batalla ecológica en contra de sus depredadores. Además, quien había ganado dos veces (1962 y 1966) el primer premio en los respectivos Salones Nacionales de Pintura, ahora ya podía representar a Colombia, como embajador que lo era, en el mundo, con sus cuadros. La reina Sofía de España lo acompañará a inagurar su muestra en Madrid, patrocinada por el Banco de Bilbao, en 1986, al igual que un año anterior el presidente francés Francois Mitterand había abierto su muestra en París, en la Maison de l'Amérique Latine.

Pero Obregón no dejaba de lado su vocación de pintor. En 1975 había dedicado cuadros al tema de la brujería, algo muy propio de la Cartagena donde imperaba la mezcla de razas y el sincretismo religioso, y donde podíamos ver un iguano-satanás y otros híbridos demoníacos. En contraposición, sus "Memorias de Grecia", del mismo 1975, deparaban una luz más armónica, una reconciliación con un pasado aún vigente.

Los "Signos del Zodiaco", de 1978 y 1979, le permiten volver a hacer del toro y la mujer desnuda un "Tauro-Virgo" de potencialidades sensuales y esotéricas, como un nuevo horóscopo que debemos descifrar, pues sus cartas ya nos son conocidas. En 1983 reunirá su pintura reciente para exhibirla en el Museo de Arte Moderno Latinoamericano de la OEA, en Washington.

Vuelven allí las mujeres desnudas de la medianoche con sus antifaces de gato, enmarcadas entre alas y flores, y una evocación azul con tintes de misterio y seducción.

Cierra también ciclos como "El último cóndor", de 1982, ahogado bajo flores de clamoroso color, la cabeza y el pico hacia abajo y las patas y uñas extendidas en una contracción última, en un postrer reflejo, en la parte superior. Sus paisajes y búhos parecen ahogarse con demasiadas flores, en exuberancia indetenible. Ello hará que sus Ángelas desnudas convivan con arpías, cabras y bestias, aun cuando en un momento dado no vacilara en llamarla "Ángela de cartulina" (1981). Un fino perfil egipcio abrumado quizás por demasiados lastres, en el cortejo que la acompaña.

También se percibe, en el fondo de todo ello, Cartagena de Indias, con sus siluetas amuralladas, nunca enfrentadas de cerca, sino más bien vistas con aura de sugerencia. Edificaciones y leyendas, que incluyen 
tanto la inquisición como la lucha contra piratas, sean franceses o ingleses. Tal el caso de Blas de Lezo, con quien Obregón se compenetra de tal forma entre 1977 y 1979 que llegará a consustanciarse con su rostro en un alucinado y visionario retrato de un antepasado loco (1977).

Serie que mantendrá en alguna forma hasta 1985 cuando su acrílico para el Banco de Bilbao en Madrid nos muestra al soldado español que defendió a Cartagena y que calvo, tuerto, manco y cojo, pero muy erguido, enfrenta aún todas las adversidades. Es el hombre herido pero imbatible que Obregón respeta y admira, en la frontalidad azul profunda de su uniforme militar y sus condecoraciones. Un héroe, no hay duda, el cual sostiene aún la delgada espada con una única mano: la izquierda. No se trata más del brutal combate, sino de la elegancia del postrer gesto.

En ese mismo año de 1985, Obregón parece cerrar su mapa plástico de Colombia, al dedicar al Amazonas una serie de cuadros sobre sus ríos: Miritiparaná, Putumayo, Japura, Atacuri. Su conocida fórmula de fondos lisos y conjuntos animales o vegetales de gran abigarramiento le permiten testimoniar un mundo hasta entonces ajeno a sus proverbiales Caribe y los Andes.

Su muestra "Copas y océanos", en 1987, y la serie "Vientos" (1990) en homenaje a Jerónimo Bosco, demuestran su terca voluntad de artista, hasta el final.

Esos vientos azules del Bosco vuelven a reavivar el diálogo con un pintor con muchas capas de significación (el Diablo y la religión, los grandes artificios flamencos, su hondura visionaria, del Paraíso a las postrimerías) y su inserción en unas costas del Caribe colombiano donde también los marinos temen las nubes oscuras asomadas en el horizonte y el silencio que no presagia nada bueno. La pintura sigue siendo una forma de conjurar lo terrible y exaltar la belleza fugitiva. El 12 de abril de 1992 muere en Cartagena de Indias.

\section{Bibliografía recomendada}

Barney Cabrera, Eugenio. (2010). "Alejandro Obregón en 1964", en Eugenio Barney Cabrera y el arte colombiano del siglo XX. Antología de textos críticos (1954-1974). Bogotá: Universidad Nacional de Colombia, pp. 182-193. 
Chico, Camilo. Obregón (2011). Bogotá: Villegas Editores.

Gaitán Durán, Jorge. (1949). La pintura de Obregón, en El Tiempo, Bogotá, 22 de mayo de 1949. Incluido en Gaitán Durán, Jorge (2004). Un solo incendio por la noche. Obra crítica. Compilación Mauricio Ramírez Gómez. Bogotá: Casa Silva.

Gómez Jaramillo, Ignacio (1945). "El pintor Alejandro Obregón", en Gómez Jaramillo, Ignacio (1987). Anotaciones de un pintor. Medellín: Autores Antioqueños, No. 39, pp. 186 a 189.

Jaramillo, Carmen María (2012). Fisuras del arte moderno en Colombia. Bogotá: Alcaldía Mayor.

Jaramillo, Carmen María (2001). Alejandro Obregón. El mago del Caribe. Bogotá: Asociación de Amigos del Museo Nacional de Colombia.

Juan Gustavo Cobo Borda. (1986). Obregón. Bogotá: Editorial La Rosa.

Londoño Vélez, Santiago (2005). “Obregón”, en Breve historia de la pintura en Colombia. Bogotá: Fondo de Cultura Económica.

Marceles Daconte, Eduardo (2010). "Obregón: la exaltación de la naturaleza", en Los recursos de la imaginación, segunda edición. Barranquilla: Gobernación del Atlántico.

Medina, Álvaro (1999). Arte y violencia en Colombia desde 1948. Bogotá: Museo de Arte Moderno.

Medina, Álvaro. (2000). "El arte del Caribe colombiano", en Los pioneros. Cartagena de Indias: Gobernación del departamento de Bolívar.

Ospina, Marco (2011). Pintura y realidad. Bogotá: Alcaldía Mayor.

Rivero, Mario (1982). "Alejandro Obregón”, en Artistas plásticos en Colombia. Los de ayer y los de hoy. Bogotá: Stamato Editores.

Traba, Marta (1986). “Obregón”, en Elogio de la locura, Feliza Bursztyn y Alejandro Obregón. Bogotá: Universidad Nacional de Colombia.

Traba, Marta (2005). Mirar en América. Caracas: Biblioteca Ayacucho.

Varios (1990). Obregón. Cinco décadas. Con textos de Marta Traba, Gabriel García Márquez, Juan García Ponce y Eduardo Serrano. México: Museo de Monterrey - Museo de Arte Moderno de México. 
Varios (1974). Alejandro Obregón: Varios (1992). Alejandro ObreAire, mar, paisaje, diálogo. Museo gón. Volumen colectivo con textos de Arte Moderno, Bogotá, junio de de Gabriel García Márquez, Álva1974. Con textos de Marta Traba, ro Mutis, Pierre Restany y Daniel Juan García Ponce, José Gómez Si- Samper Pizano. Madrid, Lerner \& cre y Juan Gustavo Cobo. Lerner.

Varios (1985). Alejandro Obregón. Varios (1996). Obregón. Volumen Pintor colombiano. Volumen colec- colectivo con textos de Ernesto tivo con textos de Belisario Betan- Samper Pizano, Fausto Pannesso, cur, Gabriel García Márquez, Álvaro Juan Gustavo Cobo Borda y EduarCepeda Samudio, Marta Traba, Juan do Serrano. Bogotá: Propal.

Gustavo Cobo Borda, Darío Ruiz Gómez y Soffy Arboleda de Vega. Bogotá: OP Gráficas.

Varios (1991). Alejandro Obregón, 1941-1991. Obras maestras. Caracas, Centro Cultural Consolidado. Este catálogo, coordinado por José María Salvador, reúne una muy amplia antología de la crítica sobre Obregón, 1944 a 1991, pp. 53 a 81.

Varios (2007). Plástica dieciocho. Bogotá, Alcaldía Mayor. Antología de la revista Plástica, dirigida por Judith Márquez, entre 1956 y 1960, y que alcanzó a publicar diecisiete números. Contiene mucha información sobre Obregón en el periodo y artículos destacados como los de Walter Engel y Arístides Menegueti, además de los de Marta Traba. 
- Alejandro Obregón - Juan Gustavo Cobo Borda
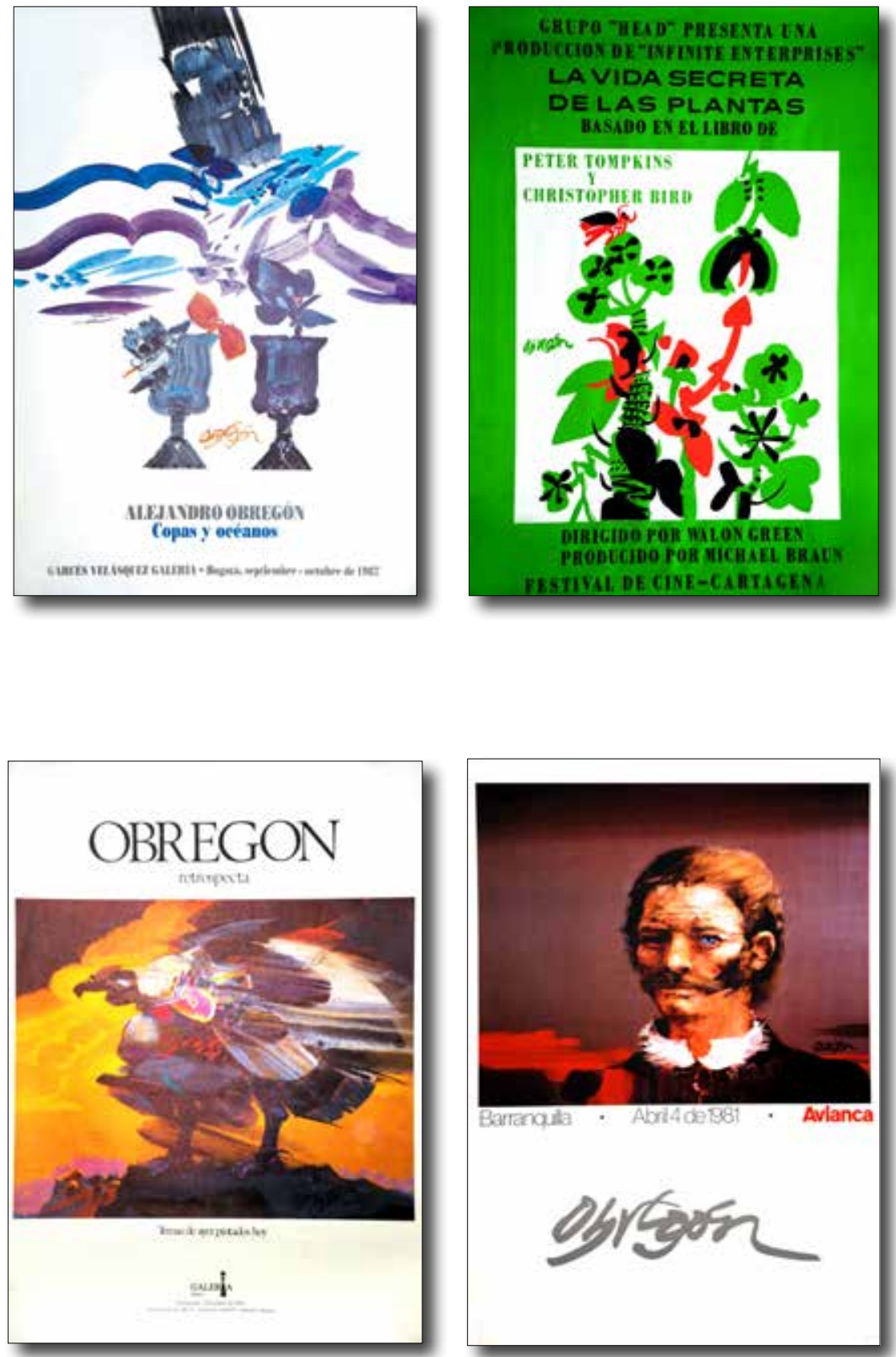

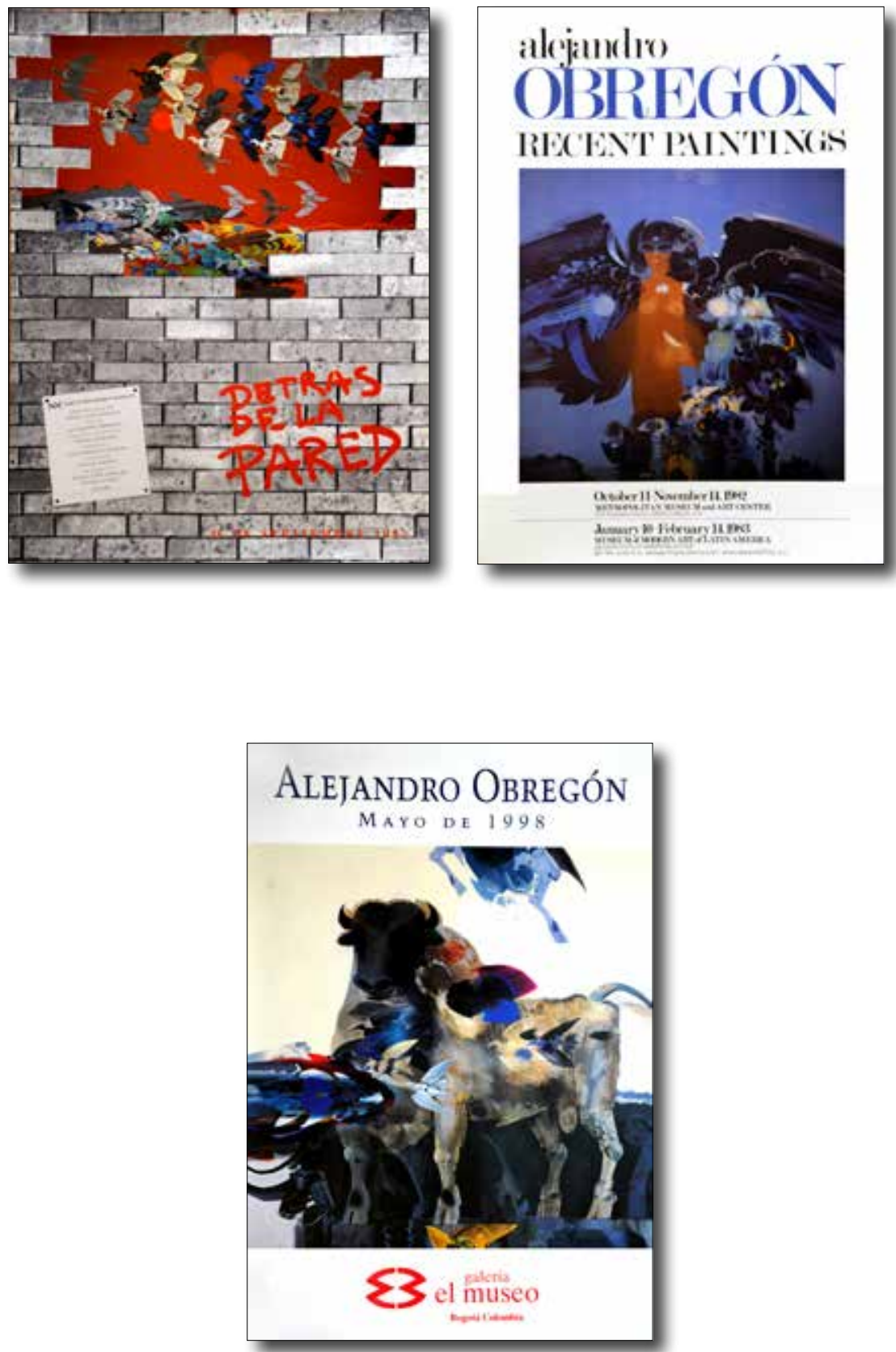